\title{
The photically evoked afterdischarge: Current concepts and potential applications
}

\author{
DONALD E. SHEARER and DONNELL CREEL \\ Veterans Administration Hospital, Salt Lake City, Utah 84148 \\ and University of Utah, Salt Lake City, Utah 84112
}

\begin{abstract}
The visually evoked potential of the rat is typically comprised of initial primary and secondary components followed by rhythmic "alpha-like" afterdischarge that may persist for several seconds. This photically evoked afterdischarge (PhAD) is sensitive to neurobiological, behavioral, and pharmacological modulation often not reflected in the primary and secondary components. The reliable acquisition of the PhAD is dependent on an optimal level of arousal and on parameters of several categories of differences that vary among albino and pigmented strains of animals, including behavior. The neurogenesis of the PhAD appears dependent on a recurrent excitatory-inhibitory cycle involving the lateral geniculate nucleus. The PhAD is highly sensitive to convulsant and anti-convulsant agents. These latter effects support the potential application of the $\mathrm{PhAD}$ as a model for thalamically active drugs useful in the treatment of epilepsy.
\end{abstract}

Following the initial report of Talbot and Marshall in 1940 of a "multiple response" to single light flashes in the anesthetized cat, a variety of waveforms following the early potentials evoked by photic stimulation have been described in both waking and anesthetized subjects (see Steriade, 1968). This paper considers the rhythmic "alpha-like" or "ringing" type of photically evoked afterdischarge.

Most research concerning these afterdischarges have been conducted using the rat, although they can be easily elicited from most laboratory animals and man (Creel, Dustman, \& Beck, 1970, 1973). In the rat primary visual cortex, the visually evoked potential (VEP) is typically comprised of an initial complex followed by a rhythmical $4-6-\mathrm{Hz}$ wave sequence. The duration of this sequence can persist for $2 \mathrm{sec}$ or longer. The specific generation of the photically evoked afterdischarge (PhAD) has been shown to be dependent upon a recurrent excitatory-inhibitory system of the lateral geniculate nucleus of the thalamus and modulated by a variety of limbic, brainstem, and thalamic systems (Bigler, 1975, 1977a; Bigler, Fleming, \& Shearer, 1976a).

Recent avenues of research have focused on the modulation of the PhAD response. The PhAD is sensitive to a host of neurobiological, behavioral, and pharmacological changes that are not reflected in the customary analysis of primary and secondary components of the VEP. This paper reviews PhADs elicited from visual cortex of the waking rat emphasizing its reliable acquisition, neurogenesis, pharmacological modulation, behavioral correlates, strain differences, and its value as a model for the evaluation of anticonvulsant agents.

Supported by the Medical Research Service of the Veterans Administration.

\section{RELIABLE ACQUISITION}

The albino strains of rats are usually the preferred subjects in the study of the elicitation of PhAD because of their docility (Fleming, Wilson, \& Shearer, 1973). The parallel development of the PhAD with maturation dictates that the rat be at least 30 days of age (Klingberg \& Schwartze, 1966), although a young adult animal, of approximately 90 days of age, would better withstand surgical anesthesia and implantation of chronic indwelling electrodes. Cortical electrodes are implanted into the calvarium overlying the visual cortices. Following surgery, postoperative recovery is allowed prior to the initiation of experimental procedures. Upon recovery from surgery, the animals are acclimated to the experimental situation. PhAD recording is usually conducted with the animals having mydriatic pupils. For a review on procedures that foster conditions of maximal $\mathrm{PhAD}$ elicitation, the reader is referred to Bigler, Fleming, and Shearer (1976b).

A photostimulator is typically used to deliver light pulses into a reflecting hemicylinder which is placed in front of a hammock holding the animal under a light restraint. Free-moving preparations are also utilized, with the electrodes being fed through a swivel slip ring, which allows head and body movements during recording. The experimental animals may be placed in a white Plexiglas box, which acts as a reflecting surface much like the hemicylinder. The pulse of light most often used is of short duration $(<10 \mu \mathrm{sec})$. The optimal frequency of stimulation has been found to be approximately $1 \mathrm{flash} / 7 \mathrm{sec}$, although rates up to $1 / 3 \mathrm{sec}$ can be used effectively. VEPs and accompanying PhADs are averaged and analyzed over a long time epoch, usually 1 to $2 \mathrm{sec}$. 


\section{STRAIN DIFFERENCES}

The photically evoked afterdischarge has received little attention with respect to observable strain differences. Kimura (1962) reported that it was difficult to demonstrate PhAD with pigmented rats of the Long-Evans strain. Kimura noted the importance of the arousal level of the animal, observing that behaviorally active rats were almost invariably poor subjects for the generation of PhAD. Rats of pigmented strains, which strıggled almost continuously, were difficult to test. Differences in temperament among rat strains are obvious. Whether or not such differences in temperament can be related to the operation of a single or polygenic factor has been debated (Wahlsten, 1972; Wilcock, 1969).

Fleming et al. (1973) compared four strains of rats varying in degrees of pigmentation and in levels of activity. Their results indicated that ease of elicitation of PhAD in the rat could be differentiated among strains and was negatively correlated with pigmentation. The PhAD was easiest to elicit in the albino and most difficult in the solid black LongEvans. Moreover, the solid black animals were unresponsive to Metrazol challenge procedures (see Pharmacological Modulation), whereas the other strains had a reliable augmentation of PhAD following Metrazol administration. It was also observed that mobility in an open-field test correlated negatively with PhAD, whereas general activity levels as measured with an activity platform and $\mathrm{PhAD}$ parameters correlated positively. It appears that enhanced activity of the reticular activating system, producing low-voltage fast EEG, blocks PhAD. The more curious and behaviorally alert pigmented strains tend to block PhAD.

The importance of strain of rat cannot be overemphasized. Differences between strains and suppliers are well known, but the greatest differences between strains are between albino and pigmented varieties. Several categories of differences exist between strains of rats: (1) optic projections, (2) sensitivity to drugs, (3) metabolism, and (4) behavior. All of these affect the PhAD. Each of these categories is discussed in the following paragraphs

Anatomical differences in the organization of the optic system of rats that vary in ocular pigmentation has been extensively documented (Creel et al., 1970; Creel \& Giolli, 1976; Montero, Bravo, \& Fernandez, 1973). The original hypothesis that differences might exist between the visual systems of an albino vs. a pigmented mammal was suggested by Sheridan (1965) when he observed differences in the learning capabilities of albino and ocularly pigmented "splitbrain" rats. Lund (1965) verified an anomalous uncrossed optic system in the albino rat. The albino rat has fewer nondecussated optic fibers, disorgan- ization of projections to the dorsal lateral geniculate nucleus, disorganization of geniculate nucleus, and subsequent disorganization of geniculostriate projections. The ocularly pigmented rat has numerically greater and better organized nondecussated optic fibers. The albino rat also has reliable slower peak latencies for those components of the evoked potential appearing in the first $100 \mathrm{msec}$ following flash illumination (Creel et al, 1970; Creel, Shearer, \& Wilson, 1974). These latency differences have also been reported in the mouse (Henry, Rhoades, \& Haythorn, 1977). There is evidence that the speed of energy conversion or charge transfer is faster with melanin pigment present (McGuiness, Corry, \& Proctor, 1974). In ongoing research, we are investigating the latency of the PhAD components. It appears that pigmented rat's $\mathrm{PhAD}$ is of faster wave latency, and persists for a shorter duration than albinic preparations.

There is evidence accumulating for significant differences between strains of rats in the metabolism of drugs. For example, the response of the liver to barbiturates is influenced by strain differences (Collins \& Lott, 1968; Creel, Shearer, \& Hall, 1976; Furner, Gram, \& Stitzel, 1969; Jori, Pugliatti, \& Santini, 1972). Results from genetic studies show that deletion of genes around the albino locus cause deficiencies in ultrastructural and regulatory enzyme systems in the kidney and liver (Garland, Satrustegui, Gluecksohn-Waelsch, \& Cori, 1976; GluecksohnWaelsch, \& Schiffman, 1975; Gluecksohn-Waelsch, Schiffman, Thorndike, \& Cori, 1974). Albino mice have longer sleep times than pigmented mice treated with either alcohol or pentobarbital (Randall \& Lester, 1974). Several albino strains of rats require lower doses of pentobarbital for lethal effects than several strains of pigmented rats (Shearer, Creel, \& Wilson, 1973). Albino rats show a nearly linear attenuation of VEP components following progressively increasing dose levels of pentobarbital, as compared with pigmented rats, who showed a "rebounding" of the VEP. The results were attributed to deficiency in the albino rat's ability to degrade pentobarbital (Creel et al., 1974).

Payan and Conard (1973) reported differences in cobalt epilepsy among strains; Racine, Burnham, Gartner, and Levitan (1973) found strain differences in development of seizure activity in rats subjected to electrical brain stimulation. To date, little research has been conducted regarding strain differences and drugs that inhibit or facilitate PhAD. The Fleming et al. (1973) study of the effects of Metrazol emphasizes the requirement for careful examination of strain differences, especially when inferences to an animal model are being suggested.

Albinism represents a genetically determined error in metabolism of one of the body's key amino acid 
systems. An error in this system has far reaching ramifications beyond phenotypical appearance of skin, hair, and eyes. The above mentioned studies indicate that secondary effects of albinism may include alterations of other systems, dependent upon normal functioning of tyrosine and related metabolism. A decade ago an argument for not using the albino animal as a model system would have been untenable. Today there is strong evidence against using albino models. Anatomically, metabolically, and physiologically, the albino rat is anomalous and unrepresentative of normally pigmented systems to which results of research are generalized. One of the categories discussed, differences in optic projections, has already been generalized to man. After verification of optic anomalies in albinic varieties of seven species of mammals in addition to the rat, studies of scalp-recorded evoked potentials in oculocutaneous albino human beings indicated a similar anomaly in man (Creel, Witkop, \& King, 1974). Guilléry, Okoro, and Witkop (1975) subsequently verified anomalous optic projections in the brain of a human oculocutaneous albino (see Creel \& Giolli, 1976, for review).

At the behavioral level, the PhAD occurs most reliably during what has been defined as a state of relaxed wakefulness (Klingberg, 1971; Sumitomo \& Klingberg, 1972). These investigators also described this state of "behavioral inhibition," i.e., the absence of general excitation, stabilized respiratory rate and muscle tonus, stablized VERs, and synchronous (or a transition towards) cortical EEG activity. In support of this, PhADs are absent or markedly suppressed during the presence of rhythmical slow-wave or "theta" EEG activity in the dorsal hippocampus (Bigler \& Fleming, 1976a, 1976b; Fleming \& Bigler, 1974; Pond \& Schwartzbaum, 1972). The novelty and excitement generated during initial exposure to the testing situation usually precludes being able to record PhAD activity until after several sessions, allowing the subject to adapt to the environment.
Albino mice have been reported to be deficient in specific behaviors when compared to pigmented littermates (DeFries, 1969; Thiessen, Owen, \& Whitset, 1970). Besides genetically determined differences in arousal levels, procedures that increase behavioral arousal such as during shock, druginduced arousal, or food deprivation-induced arousal, preclude or significantly suppress the elicitation of PhAD (Bigler \& Fleming, 1976a, 1976b; Bigler \& Fleming, 1977; Bigler, Fleming, \& Shearer, 1974; Bigler et al., 1976b; Fleming, Rhodes, Wilson, \& Shearer, 1972; Pickenhain \& Klingberg, 1965; Schwartzbaum, Kreinick, \& Gustafson, 1971). The presentation of novel or distracting stimuli have been reported to result in temporary reduction of the rat VEP and late afterdischarge components (Garcia-Austt, 1963; Heron \& Anchel, 1964). Schwartzbaum (1975) reported that elicitation of PhAD is optimally produced only during periods of lowered activity of the brainstem reticular activating system. On the other hand, procedures that decrease arousal below an optimal level, such as a period of extensive habituation training (Bigler \& Fleming, 1974; Rhodes \& Fleming, 1970) also preclude or attenuate PhAD bursting. Thus there appears to be an optimal level of behavioral arousal for the elicitation of PhADs regardless of the method used (Bigler \& Fleming, 1974; Bigler et al., 1976b). A multitude of behavioral paradigms, with emphasis on strain differences, remain to be examined in the context of PhAD research which could contribute to a comprehensive thesis as to the brain-behavioral relationship of the PhAD.

\section{NEUROGENESIS}

It has been suggested that the primary components of the visual evoked potential (P15-N25) in the rat (Figure 1) are the result of retinogeniculate activity while the secondary components are the result of a

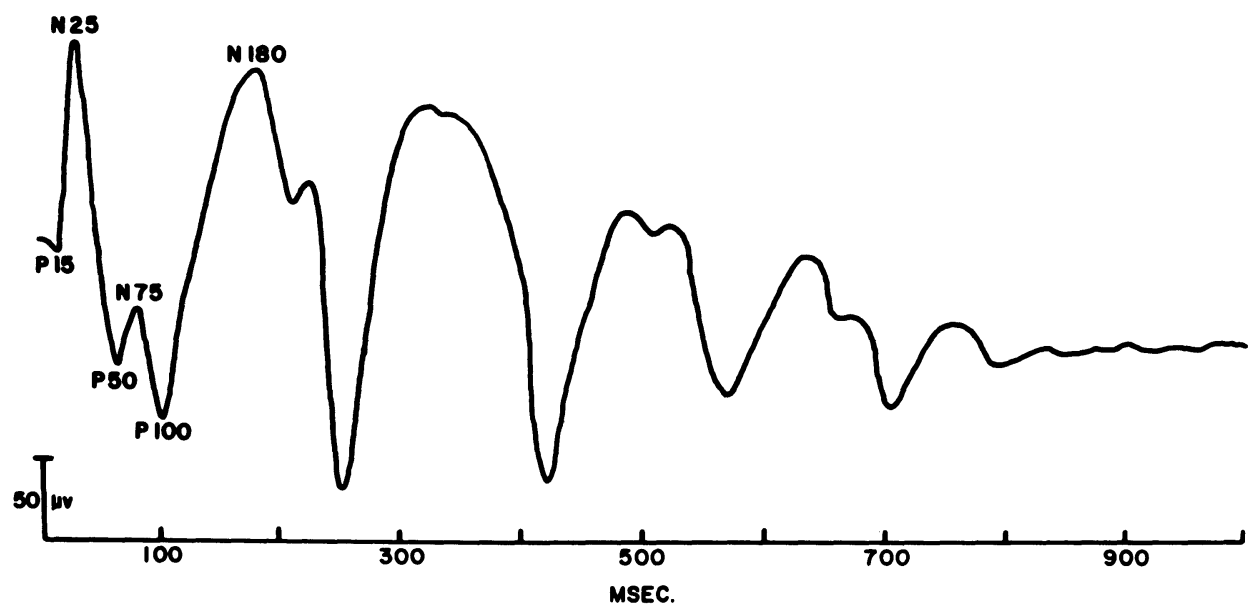

Figure 1. Representative rat averaged visually evoked potential with the accompanying photically evoked afterdischarge. Negative is up. Typical peak latencies are indicated. 
multitude of modulatory systems which include retinogeniculate connections, and various thalamic, limbic, and reticular nuclei (Beck, 1975; Creel, Dustman, \& Beck, 1974; Fleming \& Bigler, 1974).

Chalupa, Anchel, and Lindsley (1973) have reported two thalamic visual systems projecting to the cortex in the cat which mediate different aspects of the VEP. One system, the direct geniculostriate pathway, was demonstrated to be responsible for the processing of VEP primary components. The second pathway, via the pulvinar, was shown to be responsible for the processing of VEP late components and afterdischarge activity. The possibility that PhAD elaboration is generated by a system other than the dorsal lateral geniculate nucleus has been discussed by Bigler (1975). The amplitude of VEP components with particular reference to the late negative wave (N180) and its related afterdischarges has been examined by Schwartzbaum (1975). He has postulated that the late negative wave and PhADs have a similar neurogenesis.

The neurogenesis of cortical PhADs has been assumed to be dependent upon recurrent excitatoryinhibitory mechanisms of the activity cycle of the dorsal lateral geniculate nucleus (Sumitomo \& Klingberg, 1972). Bigler (1975, 1977a) has proposed a model of the neuronal basis of dorsal lateral geniculate activity in the production and elaboration of cortical PhAD activity. In brief, single photic pulses evoke late neuron population bursts in the dorsal lateral geniculate which develop into cortical PhAD activity. A detailed explanation of this effect is described by Burke and Sefton (1966), who demonstrated two types of cells in the rat dorsal lateral geniculate nucleus (dLGN): principal cells ( $P$ cells) and inhibitory interneurons (I cells). The P cells produce a large discharge following electrical stimulation of the optic tract. This initial discharge is followed by an inhibitory period. The presence of this rhythmic discharge-inhibitory sequence is an allor-none event. Burke and Sefton (1966) concluded that $P$ cells (the majority of dLGN cells) are cell bodies with axonal projections to the visual cortex via the classical geniculostriate pathways. The $P$ cells are inhibited by I cells which are, in turn, excited by axon collaterals of $\mathbf{P}$ cells, i.e., a recurrent inhibitory system.

These findings have been replicated by Fukada, Sugitani, and Iwama (1973) utilizing photic rather than electrical stimulation. Accordingly, photic stimulation appears to provoke a massive initial discharge within a population of $P$ cells, which in turn initiates a recurrent intrageniculate bursting-inhibitory pattern, which subsequently generates a sequence of rhythmic bursting. This rhythmic bursting within the dorsal lateral geniculate is then projected to primary visual cortex in the form of PhAD. This type of recurrent inhibitory system may be identical to those types of thalamic systems which are considered to be in control of cortical EEG spindling (Andersen \& Andersson, 1968; Scheibel, Davies, \& Scheibel, 1973).

Recent evidence indicates that the I cells are not strictly intrageniculate in origin. Sumitomo, Nakamura, and Iwama (1976) presented electrophysiological evidence that I cells originate in nucleus reticularis. There is no evidence that these are the same connections described by Scheibel and Scheibel (1966), nor have anatomical connections been shown to exist between the nucleus reticularis of the thalamus and the dLGN (Jones, 1975).

It appears that genesis of the PhAD is primarily a result of activity of the dorsal lateral geniculate nucleus and not activity in other subcortical areas such as the superior colliculus, posterior thalamus, reticular formation, or hippocampus. However, there is strong evidence that all these structures contribute to the modulation of dLGN activity (Bigler, 1976, 1977a; Doty, Wilson, Bartlett, \& Pecci-Saavedra, 1973; Fleming \& Bigler, 1974; Rapisardi, Wilson, \& Alvarez, 1974; Schwartzbaum, 1975).

\section{PHARMACOLOGICAL MODULATION}

Numerous experiments have demonstrated that the $\mathrm{PhAD}$ is potentiated following the perenteral administration of subconvulsive levels of pentylenetetrazol (Metrazol), and that Metrazol's specific influence, in terms of PhAD augmentation, appears to reside at the level of the dorsal lateral geniculate nucleus (Bigler, 1975). Recent investigations have indicated that the mechanism subserving Metrazol potentiation of cortical PhAD bursting has a locus in addition to the dorsal lateral geniculate nucleus (Bigler \& Eidelberg, 1976a; Bigler et al., 1976a). Accordingly, the nucleus reticularis has been shown to be the source of inhibitory input required for the development of evoked synchronous and repetitive discharges in lateral geniculate principal (P) cells (Sumitomo et al., 1976). Such evoked discharges in lateral geniculate $P$ cells drive the cortical PhAD response (Bigler, 1975). The nucleus reticularis has been suspected as a primary control center for both thalamic and cortical synchrony (Horvath \& Buser, 1976; Waszak, 1974). Similarly, rostral thalamic areas, including the nucleus reticularis, have been suggested as contributing to Metrazol-induced spindling and seizures (Feeney \& Gullotta, 1972). This evidence suggests a crucial role of the thalamic nucleus reticularis in PhAD elicitation and its augmentation by Metrazol.

Metrazol has also been demonstrated to facilitate rebound excitation (Esplin \& Zablocka-Esplin, 1969). Accordingly, it has been proposed that Metrazol potentiates PhAD bursting via a facilitating predisposition of rebound excitation, this presumably 
being localized at the diencephalic level. Similar actions likely control the Metrazol-induced visual cortical spindling and spiking. The evidence for thalamic control over visual cortical PhADs is in agreement with several models of experimental epilepsy, which have demonstrated similar diencephalic mechanisms in control of cortical afterdischarge activity (Grimm, Frazee, \& Ozabay, 1973; Kusske, 1976; Purpura,Penry, Tower, Woodbury, \& Walter, 1972; Shearer, Fleming, \& Bigler, 1976; Shearer, Fleming, Bigler, \& Wilson, 1974).

Other convulsant drugs that have been investigated include pictrotoxin, bicuculline, and strychnine (Bigler, 1977b). Fleming, Rhodes, Wilson, and Shearer (1973) reported that both picrotoxin and strychnine were ineffectual in augmenting PhAD. Consistent with previous observations, Metrazol potentiated the generation of PhADs. Interestingly, Metrazol when given in combination with strychnine or picrotoxin, did not elicit augmented PhADs. The authors attributed the results to the mode and locus of action of the agents investigated.

Another agent found to facilitate the generation of spindle activity is bemegride. Wenzel and Müller (1974) examined the effects of bemegride on the EEG and PhADs of freely moving rats. They reported that bemegride provokes spindle activity in the visual cortex and facilitates the generation of specific secondary potentials. The administration of strychnine following bemegride resulted in an antagonism of the facilitating effects of bemegride.

Anticonvulsant effects on the PhAD have received increasing amounts of attention. The effects of Tridione, Depakine, Dilantin, and saline with a Metrazol challenge to each of these drugs have been examined by Shearer et al. $(1974,1976)$. Ethosuximide, another drug with proven effects in the control of petit mal epilepsy, has been reported to attenuate PhAD and cortical spindle activity (Wenzel, Krüger, \& Müller, 1971). Diazepam has been demonstrated to also suppress both cortical PhADs and spontaneous activity from the lateral geniculate nucleus (Bigler \& Eidelberg, 1976b; Bigler, 1976). Along similar lines, it has been demonstrated by Turkanis, Chiu, Borys, and Karler (1977) that certain cannabinoids have differential effects on the elicitation of PhAD. They have reported that cannabidiol and Dilantin exerted no effect on PhAD, while $\Delta^{9}$ tetrahydrocannabinol facilitated PhAD generation much like subconvulsive dose levels of Metrazol.

Other drugs and their effects on PhAD have included various stimulants and agents causing pharmacological arousal and cholinergic blockers, such as atropine (Bigler et al., 1974; Bigler \& Fleming, 1976b; Fleming \& Bigler, 1974; Schwartzbaum, 1975; Wenzel \& Müller, 1972). Fleming, Shearer, and Creel (1974) have postulated that the N3 (N180) component of the VEP of the rat is affected by the same cholinergic and noradrenergic agents as is the PhAD. Furthermore, it seems reasonable to postulate that this late VEP component, N3 (N180), can be modulated along two different dimensions, direct cholinergic activation or by input from brainstem adrenergic structures activated by amphetamine. Interestingly, PhAD generation is markedly influenced by these same pathways, suggesting that the N3 (N180) wave of the VEP may be described as the precursor of PhAD activity (Fleming et al., 1974; Shearer, Fleming, \& Dustman, 1978).

\section{MODEL FOR EPILEPSY}

A considerable amount of attention has been directed toward the development of animal models useful in the investigation of human disease states. Of particular interest are those models relating to neurological dysfunction, especially epilepsy, and those that may be useful in the evaluation of anticonvulsant drugs. Several investigators have recently pursued these and related avenues of research utilizing differing species and techniques (Burchiel, Myers, \& Bickford, 1976; Desmedt, Niemegeers, Lewi, \& Janssen, 1976; Fowler \& Julien, 1974; Lockard, Uhlir, DeCharme, Farquahar, \& Huntsman, 1975; Losotka, Lomax, \& Rich, 1974; Meldrum, Horton, \& Toseland, 1975; Purpura et al., 1972; Shearer et al., 1976).

With respect to convulsive (Fleming et al., 1973) and anticonvulsive drug treatments (Bigler, 1976; Shearer et al., 1974, 1976), it has been demonstrated that drugs having predominantly a thalamic level of action are particularly effective in the modulation of the PhAD bursting activity of a waking rat. For example, subconvulsive levels of Metrazol readily enhance the production of PhADs (Fleming et al., 1973; Kimura, 1962; Wenzel \& Müller, 1971); similarly, it has been reported that Metrazol potentiates discharges in the lateral geniculate nucleus at frequencies coincident with cortical PhAD (Bigler, 1975). Other convulsants, such as picrotoxin and strychnine, were relatively ineffective in the augmentation of PhAD, although Metrazol reliably facilitated $\mathrm{PhAD}$ generation. These results were attributed to the locus and modes of action of the convulsants investigated (Fleming et al., 1973). On the other hand, several investigators (Kastner, Müller, \& Wenzel, 1971; Wenzel et al., 1971; Wilson \& Creel, 1972) have reported that thalamically active anticonvulsants such as trimethadione and ethosuximide suppress spindle activity in the visual cortex of unrestrained rats. Since there is evidence (see Neurogenesis) to implicate a thalamic pacing mechanism for the $\mathrm{PhAD}$, it is reasonable to assume that naturally occurring or Metrazol-potentiated PhAD could serve as an electrophysiological model for the assessment 
of drugs presumed effective in the treatment of epilepsy.

Shearer et al (1976) have demonstrated the effectiveness of this "model" by the examination of anticonvulsants having differing neural sites of action on the elicitation of PhAD. Tridione, Depakine, Dilantin, saline, and a Metrazol challenge to each of the anticonvulsants were administered to waking rats. The results were attributed to the locus of action of the anticonvulsants, with Dilantin having no reliable effect on the elicitation of PhADs as compared to the effects of the thalamically active agents. These findings support the usefulness of the PhAD as a viable model for the evaluation of thalamically active drugs, especially those useful in the treatment of epilepsy.

\section{REFERENCES}

Andersen, P., \& Andersson, S. Physiological basis of the alpha rhythm. New York: Appleton-Century-Crofts, 1968.

BECK, E.C. Electrophysiology and behavior. In M.R. Rosenzweig \& L.W. Porter (Eds.), Annual review of psychology (Vol. 26). Palo Alto: Annual Reviews, 1975. Pp. 233-262.

BIGLER, E.D. Lateral geniculate multiple-unit activity related to Metrazol potentiated after-discharges. Electroencephalography and Clinical Neurophysiology, 1975, 39, 491-497.

BIGLER, E.D. Diazepam modification of evoked and spontaneous lateral geniculate activity. Electroencephalography and Clinical Neurophysiology, 1976, 41, 428-433.

BIGLER, E.D. Neurophysiology, neuropharmacology and behavioral relationships of visual system evoked after-discharges: A review. Biobehavioral Reviews, 1977, 1, 95-112. (a)

Bigler, E.D. Comparison of the effects of bicuculline, strychnine and picrotoxin with pentylenetetrazol on photically evoked afterdischarges. Epilepsia, 1977, 18, 465-470. (b)

Bigler, E.D., \& Eidelberg, E. Principal cells in the lateral geniculate: Effects of Metrazol on capacity to after-discharge. Brain Research Bulletin, 1976, 1, 485-487. (a)

BigleR, E.D., \& EIDELBERG, E. Diazepam suppression of evoked after-discharges in rat lateral geniculate nucleus and visual cortex. Proceedings of the Western Pharmacological Society, 1976, 19, 435-438. (b)

Bigler, E.D., \& Fleming, D.E. Habituation and the occurrence of photically evoked afterdischarges in the albino rat. Bulletin of the Psychonomic Society, 1974, 4, 275-277.

Bigler, E.D., \& Fleming, D.E. Effects of shock-induced arousal on the elicitation and waveform elaboration of photically evoked afterdischarges. Physiological Psychology, 1976, 4, 86-90. (a)

Bigler, E.D., \& Fleming, D.E. Pharmacological suppression of photically evoked after-discharges in rats: Incremental dose, hippocampal EEG and behavioral activity correlates. Psychopharmacologia, 1976, 46, 73-82. (b)

Bigler, E.D., \& Fleming, D.E. Food-deprivation induced arousal: Evidence against "behavioral inhibition" in electrocortical hypersynchrony. Psychological Reports, 1977, 40, 527-531.

Bigler, E.D., Fleming, D.E., \& Shearer, D.E. Pharmacological modulation of photically evoked afterdischarge patterns in hooded Long-Evans rats. Bulletin of the Psychonomic Society, 1974, 4, 179-181.

Bigler, E.D., Fleming, D.E., \& Shearer, D.E. Metrazol potentiated after-discharge: Dose response relationships and effect of selective lesions. Pharmacology, Biochemistry and Bihavior. 1976, 5. 423-429. (a)

Bigiter. E.D., Fleming. D.E., \& Shearer, D.E. Stabilization if photically evoked after-discharge activity: Control procedures and effects of classical trace conditioning. Behavioral Biology, 1976, 16, 425-437. (b)

BurChIEL, K.J., MYERs, R.R., \& Bickford, R.G. Visual and auditory evoked responses during penicillin-induced generalizedspike-and-wave activity in cats. Epilepsia, 1976, 17, 293-311.

BURKE, W., \& SEFToN, A.J. Discharge patterns of principal cells and interneurons in lateral geniculate nucleus of rat. Journal of Physiology, 1966,187, 201-212.

Chalupa, L.M., Anchel, M.N., \& Linsley, D.B. Effects of cryogenic blocking of pulvinar upon visually evoked responses in the cortex of the cat. Experimental Neurology, 1973, 32, 112-122.

Collins, T.B., JR., \& LoTT, D.F. Stock and sex specificity in the response of rats to pentobarbital sodium. Laboratory Animal Science, 1968, 18, 192-194.

CREel, D.J., Dustman, R.E., \& Beck, E.C. Differences in visually evoked responses in albino versus hooded rats. Experimental Neurology, 1970, 29, 298-309.

Creel, D.J., Dustman, R.E., \& Beck, E.C. Visually evoked responses in the rat, guinea pig, cat, monkey and man. Experimental Neurology, 1973, 40, 351-366.

CREEL, D.J., Dustman, R.E., \& BECK, E.C. Intensity of flash illumination and the visually evoked potential of rats, guinea pigs and cats. Vision Research, 1974, 14, 725-729.

CREEL, D., \& GIOLLI, R.A. Retinogeniculate projections in albino and ocularly hypopigmented rats. Journal of Comparative Neurology, 1976, 166, 445-456.

Creel, D., Shearer, D.E., \& Hall, P.F. Differences in cytochrome P-450 of various strains of rats following chronic administration of pentobarbital. Pharmacology, Biochemistry and Behavior, 1976, 5, 705-707.

Creel, D., Shearer, D., \& Wilson, C.E. Effects of increasing dose levels of pentobarbital on visually evoked responses of albino and pigmented rats. TIT Journal of Life Sciences, $1974,4,85-92$.

CREel, D.J., Witkop, C.J., JR., \& King, R.A. Asymmetric visually evoked potentials in human albinos: Evidence for visual system anomalies. Investigative Ophthalmology, 1974, 13, 430-440.

DEFries, J.C. Pleiotropic effects of albinism in open field behavior in mice. Nature, 1969, 221, 65-66.

Desmedt, L.K.C., Niemegeers, C.J.E., LeWi, P.J., \& Janssen, P.A.J. Antagonism of maximal Metrazol seizures in rats and its relevance to an experimental classification of antiepileptic drugs. Arzneimittel-Forshung, 1976, 26, 1592-1603.

Doty, R.W., Wilson, P.D., Bartlett, J.R., \& PecciSAAVEDRA, J. Mesencephalic control of lateral geniculate nucleus in primates. I. Electrophysiology. Experimental Brain Research, 1973, 18, 189-203.

Esplin, D. W., \& Zablocka-Esplin, B. Mechanisms of action of anticonvulsants. In H. H. Jaspar et al., (Eds.), Basic mechanisms of the epilepsies. Boston: Little, Brown, 1969. Pp. 167-183.

FeEney, D.M., \& Gullotta, F.P. Suppression of seizure discharges and sleep spindles by lesions of the rostral thalamus. Brain Research, 1972, 45, 254-259.

Fleming, D.E., \& BIGLER, E.D. Relationship between photically evoked after-discharge occurrence and hippocampal EEG rhythms in restrained and unrestrained albino rats. Physiology and Behavior, 1974, 13, 757-761.

Fleming, D.E., Rhodes, L.E., Wilson, C.E., \& Shearer, D.E. Time-drug modulations of photically evoked after-discharge patterns. Physiology and Behavior, 1972, 8, 1045-1049.

Fleming, D.E., Rhodes, L.E., Wilson, C.E., \& Shearer, D.E. Differential effects of convulsive drugs on photically evoked after-discharge parameters. Psychopharmacologia, 1973, 29. 77-84.

Fleming, D.E., Shearer, D.E., \& Creel, D.J. Effect of pharmacologically-induced arousal on the evoked potential in the unanesthetized rat. Pharmacology. Biochemistry and Behavior. 1974, 2, 187-192. 
Fleming, D.E., Wilson, C.C., \& Shearer, D.E. Strain differences in the elicitation of electrocortical after-discharges. Physiology and Behavior, 1973, 10, 879-885.

FowleR, G.W., \& JulIEN, R.M. A new laboratory model for the evaluation of anti-petit mal drugs. Proceedings of the Western Pharmacological Society, 1974, 17, 107-109.

Fukada, Y., Sugrtani, M., \& Iwama, K. Flash evoked responses of two types of principal cells of the rat lateral geniculate. Brain Research, 1973, 57, 208-212.

Furner, R.L., Gram, R.E., \& Stitzel, R.E. The influence of age, sex and drug treatment on microsomal drug metabolism in four rat strains. Biochemical Pharmacology, 1969, 18, $1635-1641$.

GARCIA-AustT, E. Influences of the states of awareness upon sensory evoked potentials. Electroencephalography and Clinical Neurophysiology, 1963, Suppl. 24, pp. 77-89.

Garland, R. C., Satrustegui, J., Gluecksohn-Waelsch, S., \& CORI, C.F. Deficiency in plasma protein synthesis caused by $x$-ray-induced lethal albino alleles in mouse. Proceedings of the National Academy of Science, 1976, 73, 3376-3380.

Gluecksohn-Waelsch, S., \& Schiffman, M.B. Glutamine synthetase in new-born mice homozygous for lethal albino allelles. Developmental Biology, 1975, 45, 369-371.

Gluecksohn-Waelsch, S., Schiffman, M.B., Thorndike, J., \& CoRI, C.F. Complementation studies of lethal alleles in the mouse causing deficiencies of glucose-6-phosphatase, tyrosine aminotransferase, and serine dehydratose. Proceedings of the National Academy of Science, 1974, 71, 825-829.

Grimm, R.J., Frazee, J.G., \& Ozabay, S. After-discharge bursts in cobalt and penicillin foci in primate cortex. Electroencephalography and Clinical Neurophysiology, 1973, 34, 281-310.

GuIllery, R.W., Ororo, A.N., \& Witrop, C.J., JR. Abnormal visual pathways in the brain of a human albino. Brain Research, 1975, 96, 373-377.

HenRy, K.R., Rhondes, R.W., \& HAYThorn, M.M. Effects of ambient lighting and the albino gene on the developing visual evoked potential of the mouse. Physiological Psychology, 1977, 5, 204-208.

Heron, W., \& ANChel, H. Synchronous sensory bombardment of young rats: Effects on the electroencephalogram. Science, 1964, 145, 946-947.

HoRvath, F.E., \& Buser, P. Relationship between two types of thalamic unit patterned discharges and cortical spindle waves. Brain Research, 1976, 103, 560-567.

JoNES, E.G. Some aspects of the organization of the thalamic reticular complex. Journal of Comparative Neurology, 1975, 162, 285-308.

Jori, A., Pugliatti, C., \& Santini, V. Differences in microsomal enzyme induction between Sprague-Dawley and Long-Evans rats. Pharmacology, 1972, 7, 296-304.

Kastner, I., MÜller, M., \& Wenzel, J. Tierexperimentelle Untersuchungen $\mathrm{zu}$ Wirkung des Trimethadion auf akut und chronisch ausgelöste Krampfaktivität. Psychiatrie, Neurologie und Medizinische Psychologie, 1971, 23, 274-279.

KIMURA, D. Multiple response of visual cortex of the rat to photic stimulation. Electroencephalography and Clinical Neurophysiology, 1962, 14, 115-122.

KLINGBeRG, F. Hypersynchrony and learning. In G. Adam (Ed.), Biology of memory. New York: Plenum Press, 1971. Pp. 299-305.

KLINGberg, F., \& Schwartze, P. Über photisch ausgelöste Nachentladungen im visuellen cortex der Ratte während der ontogenese. Pflügers Archives, 1966, 292, 90-99.

KUSSKE, J.A. Interactions between thalamus and cortex in experimental epilepsy in the cat. Experimental Neurology, 1976, 50, $568-578$

Lockard, J.S., Uhlir, F., DeCharme, L.L., Farquahar, J.A., \& Huntsman, B.J. Efficacy of standard anticonvulsants in monkey model with spontaneous seizures. Epilepsia, 1975, 16, $301-316$
Losotra, W.J., Lomax, P., \& Rich, S.T. The gerbil as a model for the study of the epilepsies. Epilepsia, 1974, 15, 109-119.

Lund, D.F. Uncrossed visual pathways of hooded and albino rats. Science, $1965,149,1506-1507$.

McGuiness, J., Corry, P., \& Proctor, P. Amorphous semiconductor switching in melanins. Science, 1974, 183, 853-855.

Meldrum, B.S., HorTon, R.W., \& Toseland, P.A. A primate model for testing anticonvulsant drugs. Archives of Neurology, 1975, 32, 289-294.

Montero, V.M., Bravo, H., \& Fernandez, V. Striateprestriate cortico-cortical connections in the albino and gray rat. Brain Research, 1973, 53, 202-207.

Payan, H.M., \& Conard, J.R. Cobalt experimental epilepsy in various strains of rat. Epilepsia, 1973, 14, 415-421.

Pickenhain, L., \& Klingberg, F. Behavioral and electrophysiological changes during avoidance conditioning to light flashes in the rat. Electroencephalography and Clinical Neurophysiology, 1965, 18, 464-476.

Pond, F.J., \& Schwartzbaum, J.S. Interrelationships of hippocampal EEG and visual evoked responses during appetitive behavior in rats. Brain Research, 1972, 43, 119-137.

Pupura, D.P., Penry, J.K., Tower, D., Woodbury, D.M., \& WALTER, R. (Eds.), Experimental models of epilepsy. New York: Raven Press, 1972.

Racine, R.J., BurnhaM, W.M., Gartner, J.G., \& Levitan, D. Rates of motor seizure development in rats subjected to electrical brain stimulation: Strain and inter-stimulation interval effects. Electroencephalography and Clinical Neurophysiology, 1973, 35, 553-556.

Randall, C.L., \& Lester, D. Differential effects of ethanol and pentobarbital on sleep time in C57BL and BALB mice. Journal of Pharmacology and Experimental Therapeutics, 1974, 188, 27-33.

Rapisard, S.C., Wilson, P.D., \& Alvarez, F.L. Reticular modulation of evoked potentials at the cortex and lateral geniculate nucleus of the unanesthetized squirrel monkey. Experimental Neurology, 1974, 44, 282-294.

Rhodes, L.E., \& Fleming, D.E. Sensory restriction in the albino rat: Photically evoked after-discharge correlates. Electroencephalography and Clinical Neurophysiology, 1970, 29, 488-495.

Scheibel, M.E., Davies, T.L., \& Scheibel, A.B. On thalamic substrates of cortical synchrony. Neurology, 1973, 23, 286-288.

Scheibel, M.E., \& Scheibel, A.B. The organization of the nucleus reticularis thalami: A Golgi study. Brain Research, 1966, 1, 43-62.

SCHWARTZBAUM, J.S. Interrelationship among multiunit activity of the midbrain reticular formation, and lateral geniculate nucleus, thalamocortical arousal and behavior in rats. Journal of Comparative and Physiological Psychology, 1975, 83, 131-157.

Schartzbaum, J.S., Kreinick, C.J., \& Gustafson, J.W. Cortical evoked potentials and behavioral reactivity to photic stimuli in freely moving rats. Brain Research, 1971, 27, 295-307.

Shearer, D., Creel, D., \& Wilson, C.E. Strain differences in the response of rats to repeated injections of pentobarbitol sodium. Laboratory Animal Science, 1973, 23, 662-664.

Shearer, D.E., Fleming, D.E., \& Bigler, E.D. The photically evoked afterdischarge: A model for the study of drugs useful in the treatment of petit mal epilepsy. Epilepsia. 1976, 17, 429-435.

Shearer, D.E., Fleming, D.E., Bigler, E.D., \& Wilson, C.E. Suppression of photically evoked after-discharge bursting following administration of anticonvulsants in waking rats. Pharmacology Biochemistry and Behavior, 1974, 2, 839-842.

Shearer, D.E., Fleming, D.E., \& Dustman, R.E. Effects of dipropylacetic acid on late components of the photically evoked potential and afterdischarge in rat. Pharmacology Biochemistry and Behavior, 1978, in press.

SHERIDAN. C.C. Interocular transfer of brightness and pattern 
discrimination in normal and corpus callosum-sectioned rats. Journal of Comparative and Physiolgoical Psychology, 1965, 59, 292-294.

Steriade, M. The flash-evoked afterdischarge. Brain Research, 1968, 9, 169-212.

Sumrtomo, I., \& Klingberg, F. The role of the lateral geniculate body in the generation of photically and electrically evoked after-discharges in free moving rats. Acta Biologica et Medica Germanica, 1972, 29, 43-54.

Sumitomo, I., Nakamura, M., \& Iwama, K. Location and function of the so called interneurons of rat lateral geniculate body. Experimental Neurology, 1976, 51, 110-123.

Talbot, S.A., \& Marshall, W.H. Multiple responses in the optic tract and optic cortex of cat. American Journal of Physiology, 1940, 129, 478.

Thiessen, D.D., OWen, K., \& Whitset, M. Chromosome mapping of behavioral activities. In G. Lindzey \& D.D. Thiessen (Eds.), Contributions to behavior-genetic analysis: The mouse as a prototype. New York: Appleton-CenturyCrofts, 1970. Pp. 161-204.

Turkanis, S.A., Chiu, P., Borys, H.K. \& Karler, R. Influence of $\Delta^{9}$-tetrahydrocannabinol and cannabidiol on photically evoked afterdischarge potentials. Psychopharmacology, 1977, 52, 207-212.

Warlsten, D. Genetic experiments with animal learning: A critical review. Behavioral Biology, 1972, 7, 143-182.
WASzAK, M. Firing pattern of neurons in the rostral and ventral part of nucleus reticularis thalami during EEG spindles. Experimental Neurology, 1974, 43, 38-59.

Wenzel, J., KrüGer, E., \& Müller, M. Hemmung Pentetrazolinduzierter hypersynchroner Aktivität im thalamo-kortikalen System durch Ethosuximid. Acta Biologica et Medica Germanica, 197.1, 26, 567-572.

Wenzel, J.,\& Müller, M.Zur funktionellen Beziehung zwischen physiologischer und Pentetrazol-induzierter rhythmischer Aktivität im Hirnstrombild der freibeweglichen Ratta. Acta Biologica et Medica Germanica, 1971, 26, 533-542.

Wenzel, J., \& Müller, M. Beeinflussung photisch evozierter Potentiale im visuellen Kortex der Ratte durch Methamphetamine. Acta Biologica et Medica Germanica, 1972, 29, 463-465.

Wenzel, J., \& Müller, M. Bemegride and hypersynchronous rhythms in the electroencephalogram of the rat. Acta Biologica et Medica Germanica, 1974, 33, 275-280.

WILcock, J. Gene action and behavior: An evaluation of major gene pleiotropism. Psychology Bulletin, 1969, 72, 1-29.

Wilson, C.E., \& CREEL, D.J. Suppression of photically elicited cortical hypersynchrony in rats by trimethadione. Society for Neuroscience Abstracts, 1972, 249.

(Received for publication August 29, 1977; revision accepted February 9, 1978.) 